\title{
The Drivers for Low Energy Materials Application for Sustainable Public Housing Delivery in Nigeria
}

\author{
Jonam Jacob Lembi, Oluwafemi Kehinde Akande, Salawu Ahmed, Lilian Chioma Emechebe
}

Department of Architecture, Federal University of Technology, Minna, Nigeria

Email address:

j.lembi@futminna.edu.ng (J. J. Lembi)

To cite this ar ticle:

Jonam Jacob Lembi, Oluwafemi Kehinde Akande, Salawu Ahmed, Lilian Chioma Emechebe. The Drivers for Low Energy Materials Application for Sustainable Public Housing Delivery in Nigeria. Landscape Architecture and Regional Planning.

Vol. 6, No. 2, 2021, pp. 19-24. doi: 10.11648/j.larp.20210602.11

Received: April 17, 2021; Accepted: May 13, 2021; Published: June 25, 2021

\begin{abstract}
Rural to urban migration has been a disturbing factor in Nigeria. The urban cities have become over populated resulting into poor provision of comfortable and healthy accommodation for the citizenry. The menace has further metamorphosed into complex units of socio-economic and cultural degradation, increasing youth unemployment, poor housing delivery, and depletion of the ozone layers due to carbon dioxide emission from small electric generators called "I pass my neighbor". The situation is no longer convenient to be curtailed because of the limitations of the existing institution to provide mechanism to curtail the growing challenges. This indicates a factor of undermining urban poor of affordable and decent housing, which makes them "homeless. The research aims at conveying into luminance the drivers of low energy materials that could be employed through sustainable measures to deliver public housing in Nigeria. The objective brings forth considerations for application of low energy materials that can be integrated at the design stage to reduce the energy used in achieving comfort and limit the overall energy consumption of residential buildings in Nigeria. The purpose is to make public housing affordable and sustainable in Nigeria. The study employed the use of qualitative data analysis from relevant literatures. The results obtained indicate the high energy delivery in Nigeria's public housing reflects the overgrowing poverty level in the country. The population living in poverty has remarkably grown from 1980-2010. This factor has made it difficult for the majority poor populace to own a house due to the high cost involved in obtaining a high energy material for building construction. The study recommends a drift to low energy materials, which involves lesser energy of production and are locally found in the country, and tends to provide affordable housing to the poor living in urban centers. Hempcrete, cob, raw earth, sheep wool, bamboo, rice hull, wattle and daub, rammed earth, the mud, adobe, fire brick, are available traditional building materials with low energy richly found in Nigeria, government and private developers should adopt them in construction of dwellings to curtail the limited provided accommodation for the increasing population in urban centers and to provide decent, affordable, and sustainable accommodation to Nigerians.
\end{abstract}

Keywords: Affordable Housing, Energy, Materials, Nigeria, Public Housing

\section{Introduction}

The need for shelter by individuals is one aspect of living that keeps evolving as man and society changes. The daily migrations from rural to urban areas and population increase being experienced in developing cities around the world had increased the shortage of adequate housing. Cities have been identified to have more of these problems, with quantum deficits of housing provision, dilapidated housing, expensive housing conditions, increase in slums and polluted environment. $50 \%$ of Nigeria's 160 million citizens which are low income earners in urban centers are mostly affected by the unhealthy condition of the polluted environment and slaking economy to afford a healthy living. [8].

Many regimes of Nigerian government have shown their willingness to invest into housing provision for the poor populace. A recap of the past performance on housing policy wasn't concrete to curtail the housing deficit. [24].

Increase in urban growth in relation to socio-economic development has add up to the limited domain, resulting in total overcrowding of the populace, high cost of rent, unhealthy and slummy settlement which are glaring 
attributes of urban centers all over the country. Shortages of housing varies from one indicator to another and one estimate to the other, but all is tailored towards reflecting the extreme shortages of total housing required. According to [17] estimated the urban and rural areas housing needs in the country at total demand of 16-17 million units with an average cost of 2.5 million naira per housing unit, this identifies that Nigeria requires 35 trillion naira to finance the housing deficit of 14 million housing units. A study in Nigeria was carried on the salary structure of the public civil servants and it was found that civil servants of below level 16 in the state civil service could not afford a property costing 4.75 million naira on 25 years mortgage at $6 \%$ when $50 \%$ is devoted of his or her salary per annum to housing. Only a federal permanent secretary or a level 17 equivalent of his level with $18 \%$ mortgage can afford the same house. This shows the ineffectiveness of policies and strategies thus, the inability for most Nigerians to afford a house [4].

Addressing housing sustainability can be achieved through the resource control of renewable energy, locally affordable materials, minimizing the rate of solid and liquid waste, pollution control and optimization of local technology [24]. Exploitation of non-renewable resources from construction industries are characteristics of activities affecting the environment. Therefore, Sustainable architecture involves the use of various research-driven unique construction materials to achieve specific energy efficient goals [21].

\section{Overview of Nigeria's Provision in Housing}

Nigeria's provision in housing is one that has taken centre stage from 1999 to 2009 and this might not be unconnected with the increase in its population in the urban areas [17]. Shelter (housing) is identified to be the basic need of man. Shelter has been ranked second in hierarchy in man's basic needs, other contrary views were postulated by [26] to be the first and most important in all rights. There is no doubt that housing provides more to man than just shelter, it provides security and social services, and other auxiliary functions to mention but a few to provide a neighborhood and a habitat. [26]. This point is back up by the 199 constitution reflective of Fundamental Objective State Policy of section 16 (1) (d) " to provide suitable and adequate shelter for all citizens" and yet the provision has not been actualized which calls for public and private partnership to adequately liaise with the federal and state government to provide massive housing provision to Nigerians. According to [4] "the intervention of government in housing in Nigeria began as a result of the outbreak of bubonic plague in Lagos in the 1920s where government provided quarters for expatriate staff and selected indigenous staff". These staff quarters were in form of the council houses built in Britain for their workers and they were mainly flats. These houses provided were equally of repetitive nature and attention was geared mainly towards quantity and hence methods of housing provision were aimed at reducing the cost of providing these houses.

Nigeria and other third world developing countries are affected by the uncontrolled migration of rural dwellers into the urban centres. The situation has made the urban centres congested with insufficient infrastructure and social amenities thereby leaving the rural areas unattended to with its limited development and poverty driven economy. Urban centre dwellers have increased with a phenomenal 7\% in the period $1930 \mathrm{~s}, 10 \%$ was recorded for period of 1950 , $20 \%$ recorded for the period $1970,27 \%$ recorded for 1980 and $35 \%$ for periods in 1990. [28]. $40 \%$ and above of Nigeria's populace now dwell in the cities of numerous sizes and locations. This pointer of the overcrowded urban centres have created numerous housing decline, resulting in inadequate settlements, unhealthy environment. Such a factor denotes a $60 \%$ of the citizenry to be nucleated in a settlement and resulting in others being "houseless persons" [29]. Apart from overcrowding of the urban centres through rural-urban migration, the urban centres are now characterized with low quality of housing provision, dilapidated structures, weak and dejected dwellings, polluted environment of all kinds and collapsing structures due to overloading of occupants in the indoor spaces. [17]. Most of the structures are constructed with substandard building materials, inadequate specification of building designs, and poor supervision of building projects, and lack the basic facilities to make a suitable and nice dwelling [17]. According to [27] identified that most urban centres in Nigeria are characterized by overcrowded dwellers which reflects a densely populated buildings with polluted air, water, noise and decent disposal of solid and liquid wastes. Housing is among the most basic human needs, it is an important element towards a healthy city and a vibrant sustainable environmental development.

\subsection{Housing Shortages in Nigeria}

National Technical Working Group of vision 2020 at the 2009 conference identified that Nigeria has witnessed a $50 \%$ rapid growth on urbanization of the population living in urban areas compared to 1952 with $10 \%$, and 1993 with $38 \%$. Various studies [2, 3] have estimated a shortage of housing units to 16 million. This shortage in terms of housing for the increased population has led to the intervention of both Federal government and the State government in housing provision. An examination of past housing development plans as proposed by the government showed that, at the national level the $3^{\text {rd }}$ National Development Plan (Nigeria) designed a detail and active intervention concept of 1975-1980 to work in the provision of housing in Nigeria. The formulation of this plan by the government was to bring to an end the housing deficit eroding the country through setting up of many agencies to tackle the problems facing the housing sector. However, these problems have remained unsolved. According to [3] 
the shortage of housing in the urban area led to the contribution of private developers in housing delivery in Nigerian urban centres.

\subsection{Sustainability in Public Housing}

In the design world, sustainability construction affects the factor of economics as it regards to conceptual long and short term economic goals and building materials from local resources to cut cost of the overall building project thereby focusing on an easier construction process, low transportation costs and lower economic demand. Social sustainability lays it enfaces on building users that is the space occupants. The occupants need a sustainable plan to impact on the building morphology that creates a more functional plan that warrants future expansion [5]. A structure that can be used for a very long time portrays a flexible structure and reconstructing a new one. An increase in the efficient energy use of a building addresses its environmental sustainability; therefore, the structure should be designed in such a way that it utilizes the natural energy for both heating and other energy needed activities. Social sustainability dwells on the methods and materials that have lesser injury and limited impact on residents within the locality at period of construction and as well the reduction in highly intensive work and establishment of a harmless functional environment [5]. Therefore, public housing desires to be sustainable in order to be more affordable.

\section{Sustainability of Local Construction Constituents}

Local construction constituents are sustainable, renewable, cheap and available everywhere. Utilization of these constituents in new building techniques will promote competence of energy towards the sustainability and the reduction of in the cost of construction. The modernization and innovation implemented to meet current building standards and living conditions are posing a threat to make the traditional building material perish. Nevertheless, sustainable and green building movement provides the traditional materials to be used as a result of locally accessible resources/materials that match the need to local condition in a cost-effective manner [4].

Most traditional buildings in Nigeria were constructed with natural materials that are complex and sometimes not compatible with modern materials used today in the construction industry. Rare structures, emerald or else, can be measured sustainable, whichever in their building, use of constituents or operative lifecycle. Sustainability of such a structure has to reflect not only the lasting personified energy of the constituents in the structure but also the facilities essentially needed during building and processing of the structure and the special effects of physical extraction and removal on the veracity of the environs [7]. Life-span valuation is recycled to advance and recognize the life-span effects of structures to local weather, constituents and infrastructural boundaries [6].

\subsection{Architecture of Low Energy Materials}

The concept of architecture in the low-energy materials is to achieve sustainable residential housing development in Nigeria [31]. To bring into realization, traditional materials were used to achieve several purposes. The clay architecture is a big resource that lay it enfaces on architecture built on clay brick, compressed earth blocks, rammed earth and other concepts of earth construction. By employing mud or clay, which is readily and naturally available all over the world, it reduces the percentage usage of fossil fuel energy. The technology is very simple to manipulate. It is used as structural material for load bearing construction [23]. The Earth as one of man's ancient building constituent and greatest olden civilization utilized in different structural form is found to be cheaply accessible, very rich in compatibility, strong and required simple machinery. The Egyptian Ramasseum was built of adobe in $1300 \mathrm{BC}$ is still in existence. It was used for storing grains [30]. Also from rammed earth is the Great Wall of China built over 2000 years ago. Other examples of earthen construction with large buildings have noticeable states in cities of Iran, India, Nepal, and Yemen [30].

The Cob as local building concept using lumps formed out of the human hand and added with straw and sand which becomes very hard, similar to concrete. The olden technology does not promote mining or pollution, deforestation, nor lay its dependence on already made materials [10]. Cob and clay brick structures have similarities to adobe buildings in the world. Their climate advantage towards temperate regions cannot be over emphasized, they provide a cool interior in hot climates which stands at better advantage to wooden structures but also found to be prone to earthquake deflation. Structures from sun-dried earth are mostly found in West Africa, Eastern Europe, West Asia, Spain, North Africa, East Anglia and South America [13].

Rammed earth as a concept utilized in constructing walls of raw constituents of earth, limestone, chalk and gravel are easy to construct and water resistant. Rammed earth is characterized by compressive strength of $4.3 \mathrm{Mpa}$, which is lower to that of concrete, but preferably stronger in domestic buildings. Well executed rammed earth structures can withstand heavy load and stand the test of time as other ancient buildings that stood thousands of years. When Rammed earth is reinforced with bamboo, wood or re-bared can withstand loads coming from heavy wind and earthquakes. [7].

Daub and Wattle constitute a structural method utilize for constructing walls, where by a lattice made of wood with strips called wattle is presented to be daubed with a sticky material usually gotten from combining animal dump and straw, sand, clay and wet soil. It is a useful building material in several shares of the Globe [1]. Compressed earth brick develops from primary source of clay which has little content of moisture, it is poured into a steel press machine and well compressed mechanically 
or manually. It evolved from local constituents of rammed earth. Stabilization of soil inputs allows structures with high and thinner walls with a strong percentage of water resistance and stronger compressive strength. To mention but a few on properties of timber that makes it a rich quality of building material includes; accessibility, resistant to insects damage, availability, workability factor of easily to work upon, versatility, environmental sustainability, space friendly, flexibility, well-seasoned, cost effective and industrially active. [1]. Therefore, construction of buildings using timber can be considered to fall under principle of green architecture. Green building design provides a friendly, habitable, healthy and conserved energy structure thereby making buildings sustainable.

Rice hull is used in the production of hollow blocks thereby providing insulation. The raw materials are readily available and inexpensive, while the processing equipment can be made locally [10]. Hemp Crete is a bio-composite building material made of the internal timbered principal of the hemp plant mixed with a lime-based binder. It is utilized primarily for lining in floors, walls, and roofs as a high value invention, having hemp fibres (85\%), fibres constitute $10 \%$, and $5 \%$ of sodium carbonate, which is added as a fire defender [10]. Sheep's wool is used as an insulation material. It is fire resistant, it purifies air and it is sustainable. It forms millions of minute air pouches that trap air, serving to deliver a thermal blockade. It is natural, ecological and renewable [10]. Stone is used for walls, floors, arches and roofs. Building stones possess high strength, durability, thermal mass and easily recycled. Bamboo has advanced workable strength than steel because its fibres run axially. It is cost effective and easy to use. It is fire resistant and has low weight with high carbon sequestration capacities. Coconut encumber is utmost for structural elements like columns, window and door frames, floor and decking.

\subsection{Data Collection and Method of Assessment}

The data used in this assessment were collected from a secondary source. Firstly, data on 4 building materials with quantity and their unit energy, product and thickness of 4 building materials. The sources of the data were [10] and reports from conference of United Nations on sustainable future for energy utilization held 2010 and National Bureau of statistics- Nigerian Poverty Profile 2010. Descriptive analysis on four specific building constituents on energy consumption and emission from carbon dioxide were collected and also, properties usage of low energy materials were collected with sources from [10] and [23].

\section{Presentation of Data and Discussion of Result}

Table 1. Indicates the high energy delivery in Nigeria's public housing is highly connected to the wider population increase of the country's poverty level. Statistics from 1980 to 2010 has shown the high increase in poverty level. Therefore, low energy materials in use would cut cost from expensive materials and thereby making the houses affordable to the poor.

Table 1. Nigeria's Poverty Level in Millions.

\begin{tabular}{lllllll}
\hline Year & $\mathbf{1 9 8 0}$ & $\mathbf{1 9 8 5}$ & $\mathbf{1 9 9 2}$ & $\mathbf{1 9 9 6}$ & $\mathbf{2 0 0 4}$ & $\mathbf{2 0 1 0}$ \\
\hline Population Estimated & 65.0 & 75.0 & 91.5 & 102.3 & 126.3 & 163.0 \\
Poverty Population & 17.1 & 34.7 & 39.2 & 67.1 & 68.7 & 112.5 \\
Poverty Incidence (\%) & 27.2 & 46.3 & 42.7 & 65.6 & 54.4 & 69.0 \\
\hline
\end{tabular}

Source: [16]

Results from Table 2 identify that fire brick and concrete requires more energy to produce when compared to cement and adobe. That means more of adobe and cement would produce numerous quantity within little energy inputs while concrete and fire bricks requires more of energy to produce a desired quantity. When such is put in practice, affordable public housing would desire more of cement and adobe to fire brick and concrete.

Table 2. Energy required for producing five building constituents.

\begin{tabular}{lllll}
\hline Building Constituents & Cement & Concrete & Fired Brick & Adobe \\
\hline Quantity & Sack & $\mathrm{M}^{3}$ & $\mathrm{M}^{3}$ & $\mathrm{M}^{3}$ \\
Energy Unit & 50 & $400-500$ & 1000 & 5 \\
\hline
\end{tabular}

Source: [10].

Table 3 described the comparative energy consumption and carbon dioxide emission between various products and thickness of selected building materials. Country fired brick and wire cut brick consumes more energy and emits more carbon dioxide while Compressed Earth Block (CSEB) and concrete block consumes lesser energy and lesser emission of carbon dioxide.

Table 3. Descriptive analysis of four specific building constituents on energy consumption and emission from $\mathrm{CO}_{2}$.

\begin{tabular}{|c|c|c|c|c|}
\hline Thickness of Product & CSEB & Brick (wire cut) & Brick (country fired) & Brick (Concrete) \\
\hline Unit Number $\left(\mathrm{m}^{2}\right)$ & 40 & 87 & 112 & 20 \\
\hline Consumption Energy $\left(\mathrm{MJ} / \mathrm{m}^{2}\right)$ & 110 & 539 & 1657 & 235 \\
\hline Emission of $\mathrm{CO}_{2}\left(\mathrm{~kg} / \mathrm{m}^{2}\right)$ & 16 & 39 & 126 & 26 \\
\hline
\end{tabular}

Source: [10]

Table 4 shows various properties and usage of selected low energy materials in building construction. The local construction 
constituents are characterized by visible properties that are the determinants in the usage in the construction of buildings. The table identifies local materials of low energy to be commonly used in thermal insulation in building construction.

Table 4. Material Usage of Low Energy Constituents.

\begin{tabular}{llll}
\hline $\begin{array}{l}\text { Low energy } \\
\text { (Constituents) }\end{array}$ & $\begin{array}{l}\text { Weight }(\mathbf{k g} / \mathbf{m} \\
\text { cube) }\end{array}$ & $\begin{array}{l}\text { Thermal conductivity } \\
\text { Coefficient }(\mathbf{W} /(\mathbf{M k}))\end{array}$ & Utilization \\
\hline Hempcrete & $90-180$ & $0.44-0.063$ & Insulation of floor, roof and fiber composite \\
Sheep's wool & $15-25$ & $0.056-0.03$ & Insulation of floors, walls, roof and cladding fillings for wooden framed structures \\
Bamboo & $90-180$ & $0.044-0.065$ & Cladding fillings for wooden framed structures and load bearing buildings and roof \\
Clay & $1000-2200$ & $0.20-0.95$ & Cladding fillings for wooden framed structures and clay plasters \\
Straw & $90-100$ & $0.044-0.063$ & Roofing and load bearing structures \\
\hline
\end{tabular}

Source: [23].

\section{Recommendation}

The Federal government should strengthen the local factories in the production of low energy constituents. There should be a financial back up that will encourage the local producers to improve on the production quality thereby making it in large quantity and affordable. Hempcrete, cob, raw earth, sheep wool, bamboo, rice hull, wattle and daub, rammed earth, the mud, adobe, fire brick, etc are available traditional building materials with low energy richly found in Nigeria. To reflect on Nigeria's climate, most states and cities are considered to have hot weather conditions and therefore require the adoption of low energy materials to reduce the effect of heat and lessen the amount of energy used in such buildings. There should be adequate legislation to back up the use of traditional local materials in the construction industry to provide affordable houses and to reduce the housing deficit. The Federal and State government should liaise with Economic and Financial Crime Commission (EFCC) to monitor funds provided for public housing project. The Federal government should invest more funds into the building research institutes and higher institutions that specialize in the relevant field of study; this will highly contribute to knowledge. State and local government should be incorporated as beneficiaries in the housing delivery scheme. The study recommends among others, government to partner with Public and Private Developers to achieve sustainable public housing delivery to Nigerians.

\section{Conclusion}

The study identified available local building materials in Nigeria that are the major drivers for low energy and are richly and abundantly available for usage in the building industry. The constituents have been proven to have equivalent mechanical properties to that of modern building constituents and can stand the test of time. The traditional building materials are less expensive and required lesser energy of production when compared to modern building materials. As such, when houses are constructed with these materials, it would be affordable to the increasing poor population in Nigeria.

\section{References}

[1] Kim, J. J. (2008). "Qualities, Use, and Examples of Sustainable Building Materials". Michigan: National Pollution Prevention Centre for Higher Education.

[2] Adedeji, Y. M. D. (2005). Sustainable Low-cost Housing Technologies in Cities: Accelerated Constructio Initiatives Option. Journal of Land Use and Development Studies, 1 (1), $550-560$.

[3] Ademiluyi, A. I. \& Raji, B. A. (2008). Public and Private Developers as Agents in Urban Housing Delivery in SubSaharan Africa: The Situation in Lagos state. Humanity \& Social Science Journal, 3 (2), 143-150.

[4] Aribigbola, A. (2008). Housing Policy Formulation in Developing Countries: Evidence of Programme Implementation from Akure, Ondo State, Nigeria. Journal of Human Ecology, 23 (2), 125-134.

[5] Benros, D. and Duarte, J. P. (2009). An integrated system for providing mass customized housing Automation in Construction, 18, 310-320.

[6] Kabir, B. \& Bustani, S. A. (2009). A Review of Housing Delivery Efforts in Nigeria. Retrieved From http:/www.gla.ac.uk/media/media129767en.pdf. on $15^{\text {th }}$ September, 2019.

[7] Kadiri, K. O. (2005). Mass Housing through Earth Construction Technology in Nigeria: Pakistan Journal of Social Sciences, 3 (5), 755-760.

[8] World Bank, 2016. "Urban Development Overview" Last updated October 2016. http://www.worldbank.org/en/topic/urbandevelopment/overvie $\mathrm{w}$

[9] United Nations General Assembly UN (1987). "Report of World Commission on Environmental And Development: Our Common Future". Available from Global Issues Website: www.globalissues.org/article/427/unitednations-worldsummit-2005. Retrieved October 18, 2019.

[10] Maini, 2005. Stabilised or Unstabilised Earth Construction for Contemporary Urban Housing. International Journal of Civil Engineering, Construction and Estate Management. 1, 2, 3946, September 2014.

[11] Schwerdtfeger, F. W. 1982. Traditional Housing in African Cities- A Comparative Study of Housing in Zaria, Ibadan and Marrakech. 
[12] Uji, Z. A. 1992. "Commonality in the House Form of the Nigerian Cultures in Change" Nigerian Institute of Architects Journal, Jan-April, 26-31.

[13] Awotona, A. A. (1982). A methodology of Assessing user's Housing needs in Nigeria's human Settlement. Journal of the Nigerian Institute of Architects (NIA), 1, 3.

[14] Federal Republic of Nigeria, National Housing Policy, Federal Government Press, Lagos, 1991.

[15] ACEE (American Council for an Energy-Efficient Economy). 2017d. "Portland, OR." Last Updated Feb. 2017. http://database.acee.org/city/chicago-oil

[16] National Bureau of Statistics- Nigerian Poverty Profile 2010.

[17] Olotuah, A. O. (2001). "Housing Delivery and Financial Intermediation: An Appraisal of the Roles and Performances of Mortgage Institution in Nigeria." The Quantity Surveyor. $35,20-27$.

[18] Daramola, S. A. (1996). International Studies of Nomads and their Housing Needs, a research Report submitted to the Centre for Architectural Research and Development Overseas, University of Newcastle upon Tyne, United Kingdom.

[19] Arayela, O. (2002). Increasing housing stock at reduced cost in Nigeria. Association of Architectural Educators in Nigeria. AARCHES Journal, 2 (2), 18-24.

[20] The United Nations (UN), 1993. Report on the National Fuel wood Substitution Programme. United Nations Publications, New York, Energy Statistics Yearbook.

[21] Environmental Protection Agency (EPA). (2017). "Reduce, Reuse, Recycle." https://www.epa.gov/recycle

[22] Sustainable Cities Institute. 2013. "Water and Green infrastructure." National League of Cities. Accessed October 2019. http://www.sustainablecitiesinstitute.org/topics/waterand-Greeninfrastructure/water-101
[23] Dayaratne, R. (2011). Reinventing traditional technologies for sustainability: contemporary earth Architecture of Sri Lanka. Journal of Green building, 5, 22-33.

[24] Mustapha, I. (2002). Overview of Housing and Urban Development Programme since Independence. Housing Today-Journal of the Association of Housing Corporations of Nigeria, (1) 28-30.

[25] Akeju, A. (2007). Challenges to providing affordable housing in Nigeria. Paper presented at the $2^{\text {nd }}$ emerging urban Africa international conference on urban housing finance in Nigeria.

[26] Ebie, S. P. (2009). Public Sector Driven Housing; Achievements and Problems. Paper Presented at the 2009 Faculty of Environmental Sciences Annual lecture, Nnamdi Azikwe University, Awka.

[27] Agbola, T. and Olatubara, C. O. (2003). Private Sector Driven Housing Delivery (in Nigeria): Issues, Constraints, Challenges and Prospects. A Lead Paper Presented at the $2^{\text {nd }}$ Annual National Workshop on Private Sector Driven Housing Delivery in Nigeria, University of Lagos, Lagos, $30^{\text {th }}$ July.

[28] Okupe, L. (2002). Private Sector Initiative in Housing Development in Nigeria. How feasible. Housing Today, 1 (6), 21-26.

[29] Federal Government of Nigeria (2004). National Housing Policy (draft). Federal Government Printers, Apapa, Lagos.

[30] Anunobi, A. I. (2017). Housing Data Base for Sustainable Housing.

[31] Adebayo, A. A. (2005). Sustainable Construction in Africa. Agenda 21 positional paper. 